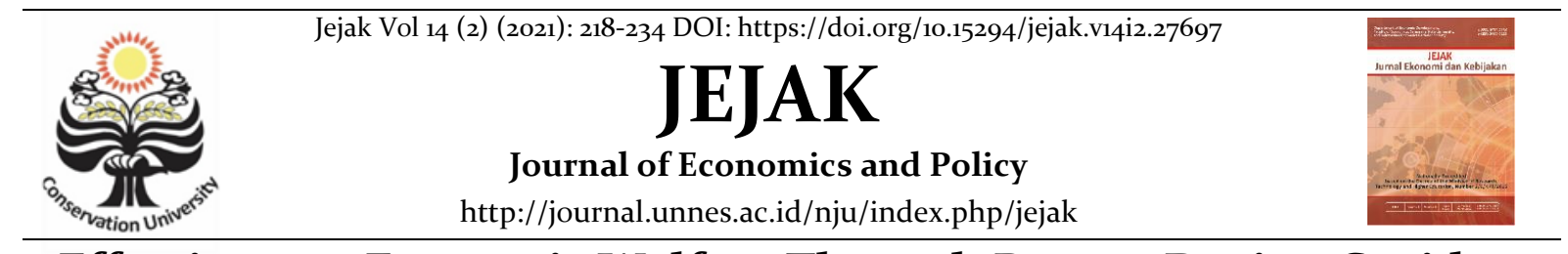

\title{
Effectiveness Economic Welfare Through Bansos During Covid-19 in Payakumbuh City
}

\author{
Nur Ari Sufiawan ${ }^{\circledR},{ }^{2}$ Nelvia Iryani \\ ${ }^{1,2}$ Faculty of economics and business, Andalas University \\ Permalink/DOI: https://doi.org/10.15294/jejak.v14i2.27697 \\ Received: May 2021; Accepted: July 2021; Published: September 2021
}

\begin{abstract}
The purpose of this study was to determine the effectiveness of mitigating the economic vulnerability of the community through the allocation of social assistance during the Covid-19 pandemic in Payakumbuh City. The data used are primary data and secondary data. Collecting data in the form of observation, documentation and interviews with a sample size of 100 respondents. The analytical method used is descriptive qualitative. The results of the analysis show 1) the input aspect with an effectiveness ratio of $60 \%$ and $65 \%$ can be said to be quite effective, meaning that KPM is right on target and utilizes social assistance appropriately for the economic benefit of the community in the midst of the Covid-19 outbreak. 2) which consists of socialization and monitoring, each with an effectiveness ratio of 100\%. 3) the output aspect of social welfare with an indicator of the level of fulfillment of needs where the percentage obtained is $74 \%$ in the category of economic welfare which is quite effective.
\end{abstract}

Key words : Effectiveness, BANSOS, Descriptive Analysis, Welfare, Pandemic

How to Cite: Sufiawan, N., \& Iryani, N. (2021). Effectiveness Economic Welfare Through Bansos During Covid-19 in Payakumbuh City. JEJAK: Jurnal Ekonomi dan Kebijakan, 14(2). doi:https://doi.org/10.15294/jejak.v14i2.27697

\footnotetext{
\ Corresponding author: Nur Ari Sufiawan

Address: Komplek Putri, Insan Cendekia Boarding School

p-ISSN 1979-715X

Harau, Jorong Lubuk Limpato, Kenagarian Tarantang, Harau

e-ISSN 2460-5123

Sumatera Barat Province

E-mail: nurarisufiawan@eb.unand.ac.id
} 


\section{INTRODUCTION}

Corona virus or severe acute respiratory syndrome coronavirus 2 (SARS$\mathrm{CoV}-2$ ) is a virus that attacks the respiratory system. The disease due to this viral infection is called COVID-19 (Corona Virus Disease 19). The virus that causes this disease is thought to have spread since December 2019 in China, then spread throughout the world.

According to WHO, Corona Virus Disease 19 (Covid-19) to date has spread to more than 122 countries, including Indonesia. The Corona virus was first confirmed in Indonesia on March 2, 2020. Citing the website of the Task Force for the Acceleration of Handling Covid-19 with the addition of 399 cases 12 April 2020, the total cases of Covid-19 in Indonesia will be 4,241 cases. Of these, 359 patients recovered, 373 died, and 3,509 were still undergoing treatment. The additional figure of 399 new cases is the highest additional number since the corona virus was first confirmed in Indonesia.

A number of countries have taken steps to control the spread of Covid-19. Including in Indonesia, some have implemented a full quarantine (lockdown) or social restrictions. Where factories restrict production, shops close, students and office workers are being asked to study and work from home. Thus, Covid-19 not only causes health problems, but also the economy.

The IMF predicts that the global economy will weaken to minus $3 \%$ in 2020 . This projection is down 6.3 points from the $3.3 \%$ estimate set in January. Meanwhile, in Indonesia, based on the statement of the Minister of Finance of the Republic of Indonesia, economic growth is estimated to decline from $5.4 \%$ to $2.5 \%$ and could even be minus $0.4 \%$.
This condition has not only disrupted the economy but has also interrupted economic movements. The crisis due to Covid-19 is currently occurring simultaneously, including in Indonesia itself, so that the impact is felt by vulnerable groups who are getting worse, including business groups that need crowds, groups of casual daily workers, street vendors, workers affected by layoffs, farmers, the poor and so on. In this case the economic activity cycle of the community has drastically decreased, so the government must take strategic policies that accelerate mitigation in dealing with the economic difficulties that befall the community. Mitigation is actions to reduce or cause the impact of a disaster on society.

Economic theories often link a high level of well-being with a higher quality of life. The higher the income, the higher the welfare as seen from the amount of their consumption. Through this understanding, welfare theory is only focused on meeting the needs of food consumption, which is said according to: "Economists see welfare as an indication of individual income (flow of income) and purchasing power of the community. Based on this understanding, the concept of welfare has a narrow meaning because by only looking at income as an indicator of economic prosperity, it means that welfare is seen as the opposite of poverty conditions".

President Joko Widodo said the government would provide various types of social assistance (bansos) to residents whose economies were affected by the corona virus pandemic which would be provided until the end of December 2020. The types of social assistance (bansos) that would be provided included: Cash social assistance, Family Hope Program (PKH), Government pre-employment cards, basic food cards, Smart Indonesia Card Program, Electricity Subsidies, Cash Work Intensive Program. 
Payakumbuh City is one of the areas in West Sumatra Province that was affected by the Covid-19 pandemic. The Payakumbuh City Government estimates that $50-60 \%$ of residents will receive assistance. In this case, the residents who will get assistance are those who are really affected by the Covid-19 pandemic, and are still in the data collection stage. The following is a table of population by sub-district in Payakumbuh City:

Tabel 1. Total Population by District in Payakumbuh City in 2019

\begin{tabular}{lccccc}
\hline & $\begin{array}{c}\text { Total } \\
\text { Population } \\
\text { (Thousands) }\end{array}$ & $\begin{array}{c}\text { Population } \\
\text { Growth } \\
\text { Rate per } \\
\text { Year }\end{array}$ & $\begin{array}{c}\text { Percentage } \\
\text { of } \\
\text { Population }\end{array}$ & $\begin{array}{c}\text { Population } \\
\text { Density (km2) }\end{array}$ & $\begin{array}{c}\text { Population } \\
\text { Gender } \\
\text { Ratio }\end{array}$ \\
\hline Payakumbuh Barat & 53,3 & 1.66 & 39.26 & 2,754 & 99.0 \\
South Payakumbuh & 11,4 & 2.16 & 8.25 & 751 & 99.0 \\
East Payakumbuh & 28.5 & 1.69 & 21.15 & 1,244 & 99.0 \\
North Payakumbuh & 32.3 & 1.40 & 23.85 & 2,194 & 99.0 \\
Latina (Lamposi Tigo & 10.2 & 1.77 & 7.89 & 1,062 & 99.0 \\
Nagori) & 1.2 & & & & \\
\hline
\end{tabular}

Source: BPS 2019

Based on the table above, the subdistricts in the city of Payakumbuh with the largest population are West Payakumbuh with 53.3 thousand, then North Payakumbuh 32.3 thousand, East Payakumbuh 28.5 thousand, South Payakumbuh with 11.4 thousand and Lamposi Tigo Nagari as many as 10.2 thousand.

Payakumbuh Mayor Riza Falepi said there are 5 types of assistance that will be distributed to the community, namely the Family Hope Program (PKH), Basic Food, Provincial Direct Cash Assistance (BLT), Ministry of Social Cash Assistance (BST) and BLT Payakumbuh City. The assistance that will be provided by the Payakumbuh city government is outside of the assistance provided by the central government and the provincial government. The total aid budget that has been prepared is around 12.5 billion.

Based on interviews from several residents of Payakumbuh, there are still residents who have not received the social assistance provided because the reason is that there is still a data collection stage by the city government together with the Social
Service, the length of the data collection process makes the community unable to receive social assistance due to the lack of information received. by society. For residents who have been registered and received assistance through $\mathrm{PKH}$, they will no longer receive BLT or BST and will be given a label or sticker. But in reality, there are still people who cheat in receiving social assistance, if they have received $\mathrm{PKH}$ and basic necessities they also receive other assistance (receiving double). And there are still inaccuracies in the targeting in the distribution of social assistance provided by the Payakumbuh City Social Service.

Data transparency will be the basis for distributing aid so that it actually reaches its destination without exception, with the target that there will be no duplicate data so that aid distribution is precise and evenly distributed. Although the government has issued a social assistance policy (bansos) and a stimulus for the community, its implementation is still not optimal. In this case, it is necessary to evaluate these assistance programs so that they are more targeted and effective in helping the welfare of the community, especially the poor. 
Economist of the Center of Reform on Economics (CORE), explained that the decline in economic growth and the implementation of Large-Scale Social Restrictions (PSBB) not only has the potential to result in large job losses, but also massive poverty increases. Vulnerable and near-poor people generally work in the informal sector and many are highly dependent on government assistance. With the spread of the pandemic and the implementation of PSBB in the city of Payakumbuh, many groups of people have experienced a decrease in income and even have to lose their livelihoods, especially those who work in the informal sector. Moreover, if the social assistance provided by the Government is insufficient or arrives too late, more and more vulnerable and nearpoor groups will fall below the poverty line.

$$
\text { According to Emalia (2013) }
$$

Effectiveness comes from the word effective which has several meanings, including: 1) there is an effect, 2) it brings results, is useful (action effort) and takes effect. From this word comes the word effectiveness which is defined by action with circumstances, influence, impression, efficacy and success. Effectiveness is the suitability of the output with the stated goals.

According to Mursyidah (2017), a program or activity is considered effective if the output produced can meet the expected objectives. Meanwhile, according to (Mardiasmo, 2010), effectiveness is a measure of the success or failure of an organization to achieve its goals. If an organization has succeeded in achieving its goals, then the organization is said to have run effectively.

According to Makmur (2011) measuring the effectiveness of a program can be done using the following indicators: 1) The accuracy of timing The use of the right time will create the effectiveness of achieving predetermined goals; 2) Accuracy in making choices Accuracy in making choices is the accuracy in choosing a job, method, object and so on; 3) Accuracy in determining goals An organization will try to achieve the goals that they have agreed upon previously and are usually stated in a written document which is more strategic in nature, so that it becomes a guideline for the implementation of an organization's activities; 4) Accuracy and accuracy of targets In line with what we mentioned above, that goals are more long-term and strategic in nature.

Mitigation are actions to reduce or minimize the impact of a disaster on society. Meanwhile, disaster mitigation (article 1 paragraph 6 PP No. 21 of 2008 concerning the implementation of disaster management) is a series of efforts to reduce disaster risk, both through physical development and awareness and increased capacity to face disasters.

Social assistance (Dinas Sosial, 2014) is assistance that is temporary in nature provided to the poor, with the intention that they can improve their lives naturally.

Mitigation of the vulnerability of the people's economic welfare during the Covid-19 pandemic in the city of Payakumbuh provided by the government in the form of social assistance.

The types of social assistance provided by the Payakumbuh city government to people affected by the Covid-19 pandemic include: 1) Social Cash Assistance (BST) Kementerian Sosial; 2) Provincial Cash Direct Assistance; 3) Payakumbuh City Direct Cash Assistance; 4) The Family Hope Program (PKH) (Kementerian Sosial, 2011) is a program of providing conditional social assistance to poor families who are designated as PKH recipient families; 5) Basic food.

The criteria for the community receiving social assistance from the Government affected by the Covid-19 pandemic in the city of Payakumbuh: 1) People who are included in the Integrated Social Welfare Data (DTKS) 
Kemensos RI, do not get the social assistance program for the Family Hope Program (PKH) and groceries; 2) Other vulnerable groups are poor families, the elderly, people with disabilities, women with economic vulnerability, are not included in the Integrated Social Welfare Data and do not receive $\mathrm{PKH}$ social assistance programs and basic food and other social assistance programs; 3) Informal sector workers who are directly affected by pandemic prevention policies such as mobile traders, small traders, public transport drivers, motorcycle taxis, workers who are laid off or laid off or other informal sectors that have a direct impact on economic activity; 4) People who returned home from other areas due to the impact of local government policies that limit social and economic activities and resettled in the city of Payakumbuh in the period since the Covid-19 emergency response was treated; 5) Families with people under monitoring (ODP) and patients on treatment (PDP).

From several previous studies stated that social assistance provided by the Government has been effectively implemented. According to Yuliantari (2018), "The effectiveness of social assistance for the welfare of the people in Badung Regency is quite effective" where the results obtained are 1) The effectiveness of social assistance for the welfare of the people in Badung Regency is quite effective; 2 ) Social assistance has no significant impact on the welfare of society in Badung regency.

According to Dinda Pramisita \& Made Suryana (2020) "The effectiveness and influence of social assistance on the level of basic needs of the elderly in Mengwi District, Badung Regency", based on the perception of the beneficiary community, has been very effective, seen from the output variable, namely the increase in basic needs which reached $77.4 \%$ of 98 elderly population in
Mengwi District, so it can be said that this Elderly Social Assistance can increase the fulfillment of the basic needs of the elderly population there.

Furthermore, according to Infitah, et al. (2018) with the research title "Effectiveness of the Family Hope Program (PKH) in Source of Success Village, Mayang District, Jember Regency" which shows that PKH in Source of Success Village, Mayang District, Jember Regency has been effective in aspects of input, process and output in the fields of education and welfare. social. The percentage of research results on the input aspect shows the results of $68.3 \%$, the process aspect is $84 \%$ and the output of the education sector for the criteria for school-age children enrolled in the education unit is $99 \%$ and the percentage of attendance of school-age children is $88 \%$ and social welfare is $84 \%$. Meanwhile, in the health sector output aspect, the KPM category aged $1-5$ years has not been effective.

According to Ana Rosaliana, et al. (2019) with the previous research title "Effectiveness of the Implementation of the Non-Cash Food Assistance Program (BPNT) in Wonocolo District, Surabaya City", with The results of the research obtained are: 1) Accuracy of Timing, the timing of the implementation of the NonCash Food Aid program (BPNT), especially in the process of distributing aid, both aid funds received by BPNT Beneficiary Families and ewarong operational assistance funds are carried out right time according to a predetermined schedule; 2) Accuracy in Deciding Options, the choice of target recipients of the BPNT program still needs improvement. Whereas the choice of needs (rice and eggs) has also not been fully effective because there are restrictions in terms of exchanging food needs; 3 ) Accuracy in setting goals, in realizing the objectives of the BPNT program, the government's strategic steps are quite good, but have not been effective and still need improvement; 4) Accuracy of Goals, in this 
case focusing on the target of using the Prosperous Family Card which is an electronic card for the distribution of BPNT programs is still considered ineffective, because there are still some obstacles and problems that still occur.

According to Aldino Putra (2018) with the research title "Effectiveness of the Implementation of Social Assistance Programs in the Community in Palu City (Study on Joint Business Groups)". The results showed that in the implementation of Kube were carried in Palu has not run Effective and maximum, in view of the criteria put forward by Duncan that the first process of Achievement has not shown the desired results, due to obstructed its budget received by implementer in this case the Social Service Palu, so that at the time of his becoming obstructed, and Goals for this help researchers feel right on target because it does not follow the rules, and there are others who do not have links with Kube have contributed to intervene in selecting targets and want to capitalize right this assistance, both on Integration in which the government its self does not disseminate it in the draw after researchers conducted a search to village Lere and to the beneficiary communities say for this program in 2016 did not exist in doing socialization and contradictory with what was said by the social services themselves that their dissemination in the region but only once.

Jianguo's (2014) statement that said in 2006, China clearly stated that in 2020, a comprehensive social security system that covers urban and rural residents will basically be established. Since then, the rate of improvement in social welfare for the elderly has increased.

\section{METHOD}

In this study the data used are qualitative data, namely data obtained in the form of public opinion from interviews. From the opinions obtained will be further analyzed in data analysis.

This study uses primary data and secondary data. Primary data that researchers need is data from informants on social assistance Beneficiary Families (KPM) in Payakumbuh City which are obtained from the results of interviews that researchers distribute. The secondary data that researchers need are the types of social assistance distributed during the Covid-19 period, the stages of distributing social assistance to KPM (Beneficiary Families) in Payakumbuh City. Researchers obtained interview data from documentation through informant sources, namely: The person in charge of each covid-19 social assistance at the Payakumbuh City Social Service, and other data sources obtained from BPS.

The population in this study is KPM (Beneficiary Family) social assistance in 5 districts of Payakumbuh City. The sample used in this study used the Slovin formula:

$$
\mathrm{n}=\frac{N}{1+N x e^{2}}
$$

An error tolerance of $10 \%$ (o.1), so that calculations using the Slovin formula for PKM (Beneficiary Family Beneficiaries) are as follows:

$$
\begin{aligned}
& \mathrm{n}=\frac{25.761}{1+\left(25.761 \times 0,1^{2}\right)} \\
& \mathrm{n}=\frac{25.761}{1+(25.761 \times 0,01)} \\
& \mathrm{n}=\frac{25.761}{258,61} \\
& \mathrm{n}=99,6 \\
& \mathrm{n}=100 \mathrm{KPM}
\end{aligned}
$$


Based on the calculation, in this study, the total sample size was 99.6 KPM rounded to 100 KPM which will then become respondents in this study.

The sampling was carried out using proportionate stratified random sampling, which is a technique used if the population has members or elements that are not homogeneous and proportionally stratified. which are spread across 5 districts in the city of Payakumbuh.

The variables in this study are: First, Effectiveness is the conformity of output with the objectives set. The effectiveness of Social Assistance in Payakumbuh City can be calculated using the formula for calculating the level of effectiveness as follows:

$$
\text { Effectiveness }=\frac{\text { Realization }}{\text { Target }} \text { X 100\% }
$$

The variables used to measure the effectiveness of social assistance are the Input, Process, and Output variables.

The criteria used to measure effectiveness are shown in table 2 below:

Table 2. Standards Measures Effectiveness according to Reference Ratio research and development agency of Ministry of Internal Affairs

\begin{tabular}{ll}
\hline Effectiveness Ratio & Achievement Level \\
\hline Under 40 & Very ineffective \\
$40-59,9$ & Ineffective \\
$60-79,9$ & Effective enough \\
Above 80 & Very effective \\
\hline
\end{tabular}

Source: Research and Development Agency of Ministry of Internal Affairs, 1991

Second, Social assistance (bansos), which is temporary assistance provided to the poor, with the intention that they can improve their lives properly.

This study used descriptive qualitative method. This method is used to answer research objectives regarding the effectiveness of mitigating the allocation of social assistance in the economic welfare of the people of Payakumbuh during the Covid-19 pandemic.

The steps of the research data analysis process are as follows: 1) Data analysis, namely examining all data obtained through interviews, observation and documentation study; 2) Data assessment is done by categorizing the data with the relevant recording system and criticizing the data that has been collected; 3) Data analysis and interpretation is carried out by analyzing the data with an intellectual understanding that is built on the basis of empirical experience of the data, facts and information that has been collected. Then present the data grouping obtained from interviews with respondents; 4) Inference of the results of analysis and interpretation of data; 5) Presentation of the results of analysis and interpretation of data in narrative form or depicted in words and sentences.

\section{RESULTS AND DISCUSSION}

This research was conducted in the city of Payakumbuh consisting of 5 districts, including West Payakumbuh, South Payakumbuh, East Payakumbuh, North Payakumbuh, and Latina (Lamposi Tigo Nagori) districts.

Economic vulnerability will affect the welfare of the community so that it will have an impact on the level of social ability of the community. The inability from an economic point of view to meet basic food and non-food needs as measured from the expenditure side is seen as poverty. So the concept of poverty itself can be interpreted as a concept of the ability to meet basic needs.

During the current pandemic, this macroeconomic indicator is a very important thing to be a top priority for the Payakumbuh city government, to pay attention to the poverty 
rate. With the emergence of a pandemic that shook the whole world, residents of Payakumbuh also felt the impact of this phenomenon, with the Large-Scale Social Restrictions (PSBB) implemented in Payakumbuh, not only has the potential to result in a decrease in income and even loss of employment in large numbers, but also increase poverty overall. massive. Vulnerable and near-poor people generally work in the informal sector and many are highly dependent on government assistance.

Various types of assistance programs are provided by the Payakumbuh City Government to maintain people's lives, especially informal workers who are greatly affected by the current pandemic.

The following table 3 Types of social assistance provided to the community of Payakumbuh city and the number of family beneficiaries of social assistance.

Table 3. Types of Payakumbuh City Social Assistance

\begin{tabular}{lc}
\hline Types of Social Assistance & Total PKM \\
\hline BST Kemensos & 4,067 PKM \\
Provincial BLT & 3,216 PKM \\
City BLT & 8,305 PKM \\
PKH & 3,840 PKM \\
Groceries & 6,333 PKM \\
\hline Total & $\mathbf{2 5 , 7 6 1 ~ P K M ~}$ \\
\hline
\end{tabular}

Source: Social Agency, 2020

Based on the table above, the types of social assistance provided by the Payakumbuh city government consist of 5 types of assistance for people affected by the COVID-19 pandemic. The types of assistance include BST (Cash Social Assistance) of the Ministry of Social Affairs as much as 4,067 KPM, BLT (Direct Assistance) Cash) Provinces as many as 3,216 KPM, BLT (Direct Cash Assistance) as many as 8,305 KPM, PKH (Program Keluarga Harapan) as many as 3,840 KPM and groceries totaling 6,333 KPM.
This study involved 100 respondents of KPM (Beneficiary Family), after a proportional calculation. Furthermore, sampling was carried out using proportionate stratified random sampling which was spread in each of the 5 subdistricts in the city of Payakumbuh. The following is table 4 of the distribution of social assistance recipients in 5 districts in Payakumbuh City:

Table 4. Distribution of Social Aid Recipients in 5 Districts in Payakumbuh City

\begin{tabular}{lc}
\hline \multicolumn{1}{c}{ Subdistrict } & Total KPM \\
\hline West Payakumbuh & $34 \mathrm{KPM}$ \\
South Payakumbuh & $16 \mathrm{KPM}$ \\
East Payakumbuh & $23 \mathrm{KPM}$ \\
North Payakumbuh & $18 \mathrm{KPM}$ \\
Latina (Lamposi Tigo Nagori) & $9 \mathrm{KPM}$ \\
\hline Total & $\mathbf{1 0 0}$ KPM \\
\hline
\end{tabular}

Source: data processed by researchers 2020

This study involved 100 respondents from KPM (Beneficiary Families), after proportional calculations were carried out. Furthermore, sampling was carried out using proportionate stratified random sampling spread over each of the 5 sub-districts in the city of Payakumbuh. Then the following results were obtained, namely 34 respondents from West Payakumbuh, 23 respondents from East Payakumbuh, 18 respondents from North Payakumbuh, 16 respondents from South Payakumbuh and Latina (Lamposi Tigo Nagari) as many as 9 respondents. The data collection method used interviews with a list of interview questions sorted from the characteristics of the respondents, and information from respondents consisting of the type of social assistance received, nominal, stages of receiving social assistance, location of receiving social assistance, benefits of social assistance, to the effectiveness of social assistance provided by Government according to respondents' views. 
Respondents in this study gave their responses regarding the effectiveness of the allocation of social assistance provided by the Government in the vulnerability of the community's economic welfare during the COVID-19 pandemic in the city of Payakumbuh.

The list of questions is clustered by the researcher and then percentage is based on their respective categories in order to be able to interpret the results in the form of numbers from the total respondents who are beneficiary families, where the respondent is representative or can represent the entire family of beneficiaries of social assistance in the city of Payakumbuh.

The method of analysis used in this research is a qualitative descriptive approach, namely the data collected is not in the form of numbers but data from interviews, field notes, personal documents and other official documents. So that the purpose of this study is to describe the empirical reality of the phenomenon in depth, detail and thoroughly, then the responses are described with descriptive analysis where the presentation of the results of the analysis and interpretation of the data is in narrative form or described in words and sentences.

Respondents' opinions about the benefits of social assistance provided by the Government during the Covid-19 pandemic are presented in the following figure:

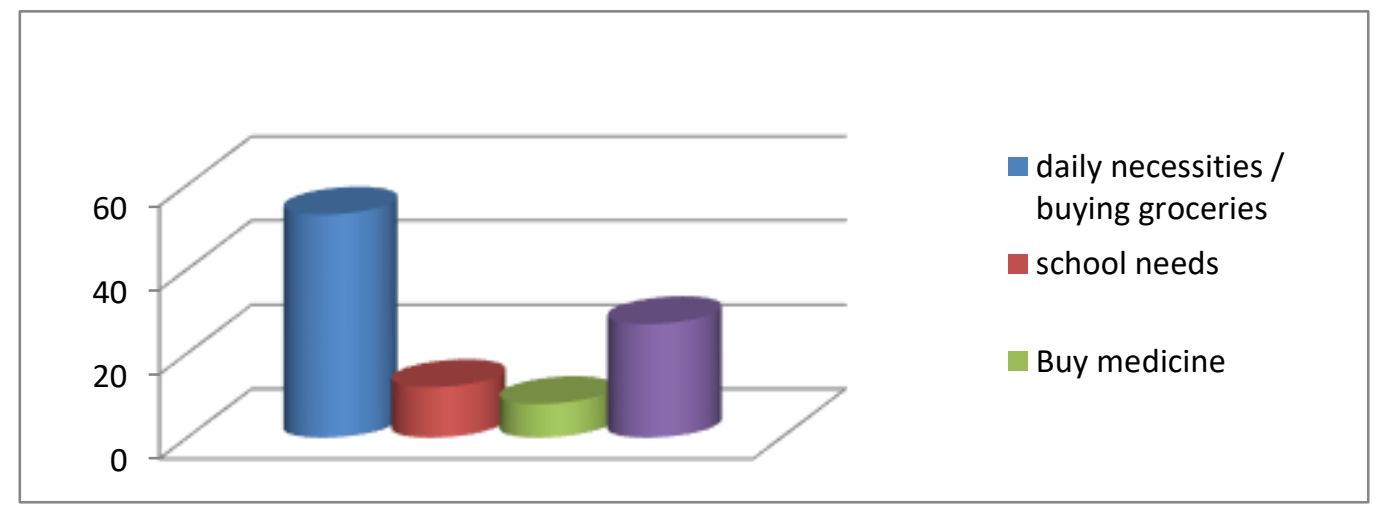

Source: processed by researchers 2020

Figure 1. Respondents' Opinion About the Benefits of Social Assistance

Based on the picture above, the majority of respondents as much as $53 \%$ thought that social assistance was useful for daily needs or buying food and $12 \%$ gave an opinion for school needs. This means that during the current Covid-19 pandemic, social assistance provided by the Government is very beneficial for the economic welfare of the people in the city of Payakumbuh. Some respondents thought that the benefits of social assistance were used to purchase drugs and business capital, namely $8 \%$ and $27 \%$.

Respondents' opinions about the effectiveness of social assistance provided by the Government during the Covid-19 pandemic can be presented in the following figure: 


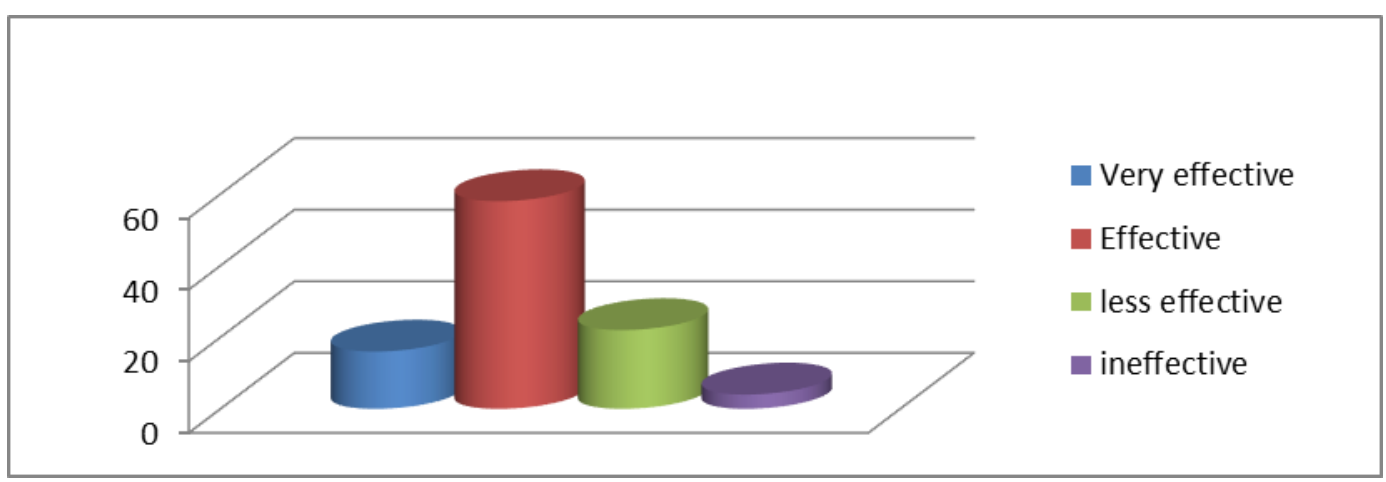

Source: processed by researchers 2020

Figure 2. Respondents' Opinions on the Effectiveness of Social Assistance

From the picture above, $58 \%$ of respondents think that social assistance that has been distributed is effective, and $16 \%$ of respondents think that social assistance provided by the Government is very effective. This means that this assistance is very beneficial for the people in the city of Payakumbuh by explaining the reasons that the assistance has been fully provided for economic welfare, especially in meeting their daily needs. Some respondents expressed their opinion that $22 \%$ thought it was less effective and even $4 \%$ of respondents thought it was not effective, with the social assistance that has been provided by the Government.

The respondent's opinion about the target of social assistance distribution can be presented in the following figure:

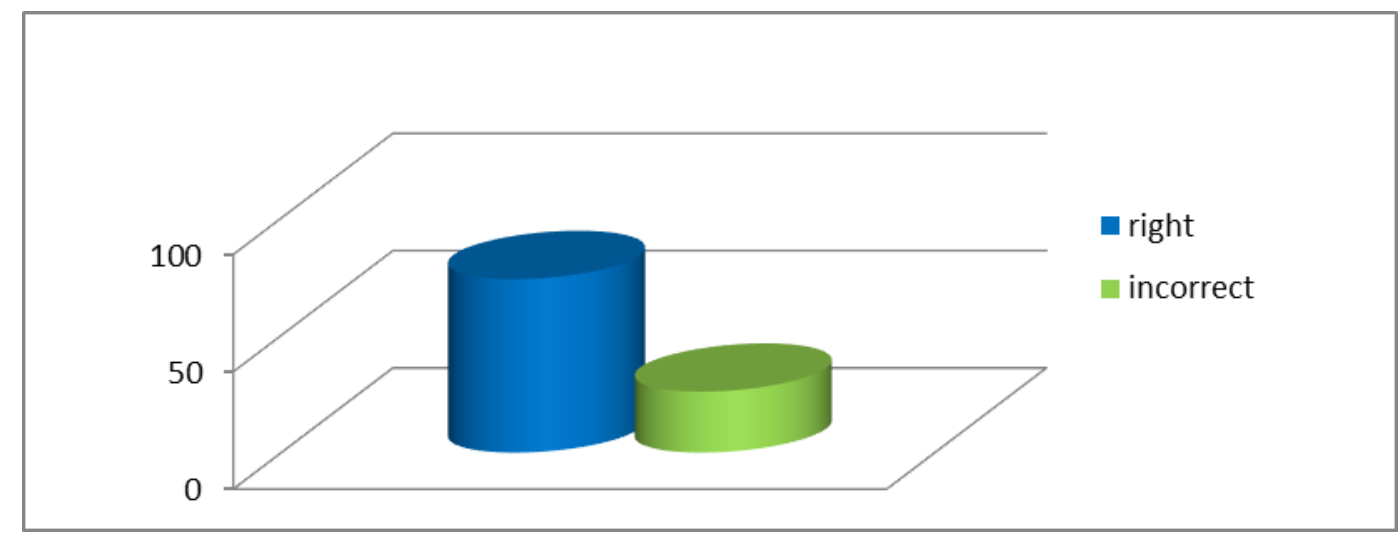

Source: processed by researchers 2020

Figure 3. Respondents' Opinions on the Target of Social Assistance Distribution

Based on the results of the analysis of interviews with respondents, it was found that $74 \%$ of the distribution targets for social assistance were right on target and $26 \%$ were not on target. Which means because the distribution of social assistance is given effectively to people who directly feel the impact of the Covid-19 pandemic.

The social assistance program provided by the Government to overcome the vulnerability of the economic welfare of the community only during the Covid-19 pandemic which affects vulnerable groups, informal workers who directly experience the prevention of the Covid-19 pandemic consists of BST (Cash Social Assistance) of the Ministry of Social Affairs, BLT (Provincial Direct Cash Assistance, City BLT (Direct Cash Assistance), $\mathrm{PKH}$ and groceries.

The existence of the Covid-19 social assistance program has previously been socialized by related parties with the aim of providing information for people affected by the Covid-19 pandemic. So that they can provide 
accurate data information to the Office of Social Affairs, for the KPM community to report to the local village head in order to obtain social assistance programmed by the Government.

Details of the distribution period of the 5 types of Covid-19 social assistance based on the results of interviews with each person in charge of social assistance by the Payakumbuh City Social Service:

First, BST Ministry of Social Affairs (Kemensos). Based on data from the Social Affairs of the city of Payakumbuh, the Ministry of Social Affairs' BST data collection starts in March for people who enter the Integrated Social Welfare Data (DTKS) of the Ministry of Social Affairs. This Social Assistance Program is given to the people of Payakumbuh starting from April to December.

The following is a table of 5 stages of distribution and the number of KPM who receive BST from the Ministry of Social Affairs:

Table 5. Stages of Distribution of the Ministry of Social Affairs BST in Payakumbuh

\begin{tabular}{lccl} 
Month & Stages & $\begin{array}{c}\text { Total } \\
\text { KPM }\end{array}$ & Information \\
\hline Early & & 3789 KPM & \\
March & & & \\
April & 1 & $393 \mathrm{KPM}$ & Expansion \\
May & 2 & $115 \mathrm{KPM}$ & Expansion \\
June & 3 & $137 \mathrm{KPM}$ & Expansion \\
July & 4 & $4124 \mathrm{KPM}$ & \\
August & 5 & $4124 \mathrm{KPM}$ & \\
September & 6 & $4067 \mathrm{KPM}$ & \\
\hline
\end{tabular}

Source: Social Agency, 2020

Based on the table above, from April to June there has been an expansion of the receipt of social assistance for KPM, after the assistance was given, the Payakumbuh Social Service Agency monitors the program that has been implemented, namely by verifying the KPM community data.

The amount of funds distributed in this program from April to June is IDR 60o,0oo/ month, July to October IDR 300,000/ month. And now the Ministry of Social Affairs BST has entered the 7 th stage in October with a fund of IDR 300,000/ month. Funds were channeled through HIMBARA (Association of State Banks) and post offices. For people who have received BST from the Ministry of Social Affairs, they will be given a red label or sticker at the house of each KPM.

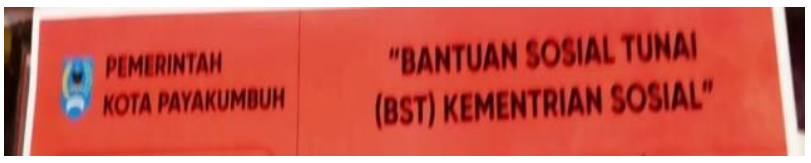

Source: primary data

Figure 4. Label or Sticker BST Kemensos

Second, provincial BLT. In this program, people who receive Provincial BLT are those who cannot receive social assistance through the Ministry of Social Affairs' BST, so they will be transferred to Provincial BLT. The number of KPM that received Provincial BLT was 3,216 KPM. This Social Assistance Program is given to the people of Payakumbuh starting from May to July or only around 3 months. With a monthly amount of funds of IDR 60o,ooo. Funds are channeled through HIMBARA (Association of State Banks) and post offices.

For people who have received Provincial BLT, they will be given a yellow label or sticker at the house of each KPM.

\section{"BANTUAN LANGSUNG TUNA (BLT) PROVINSI"}

Source: primary data

Figure 5. Label or Sticker Provincial BLT

Third, City BLT. This program is the same as the Provincial BLT program with the implementation of beneficiary families, namely, people who do not receive social assistance 
through the Ministry of Social Affairs BST and Provincial BLT are transferred to City BLT. The number of KPMs who received City BLT social assistance was $8,305 \mathrm{KPM}$, which was distributed to the community starting from May to July or ranged from only 3 months with the amount of funds channeled of Rp. 60o,ooo where the funds were channeled through HIMBARA (Association of State Banks) and post offices.

For people who have received City BLT, they will be given an orange label or sticker at the house of each KPM.

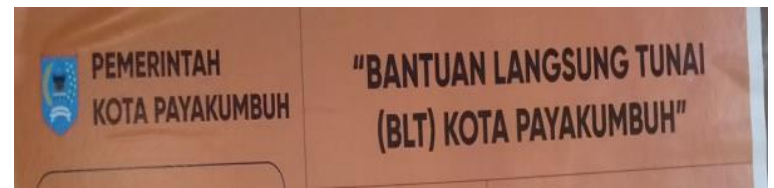

Source: primary data

Figure 6. Label or Sticker City BLT

Fourth, PKH (Program Keluarga Harapan). This assistance program is a sustainable social assistance program. Before covid-19. PKH is a social assistance program that has long been a program of the Ministry of Social Affairs which started in 2007.

Communities who receive $\mathrm{PKH}$ benefits can also receive basic food social assistance types, but those who are recorded as only receiving basic necessities cannot receive $\mathrm{PKH}$. If $\mathrm{PKH}$ beneficiaries receive basic necessities too, then what is given is $15 \mathrm{~kg}$ of rice in a period of 3 months ( 3 stages), namely from August to October.

The number of KPM who received this social assistance was 3,840 KPM. This assistance program is a form of distribution of funds in accordance with the PKH social assistance index that has been determined by the Ministry of Social Affairs, after which there will be assistance which will also provide material such as socialization of savings which is held in a meeting at least 1 month once.

Based on the results of interviews with the person in charge of the social service PKH social assistance program, data on the distribution of social assistance will be evaluated this November.

For people who have received $\mathrm{PKH}$ (Program Keluarga Harapan) will be given a green label or sticker at home every KPM.

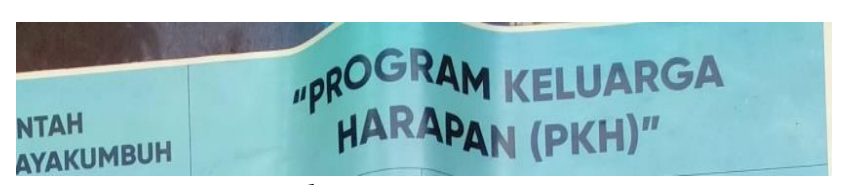

Source: primary data

Figure 7. Label or Sticker PKH

This social assistance program is distributed only in one stage, namely in August. The staple foods provided were in the form of food needs worth Rp. 200,00o which were given to Brilink agents. The number of beneficiaries who received basic food assistance was 6,333 KPM.

For people who have received basic foodstuffs, they will be given a green label or sticker at the house of each KPM.

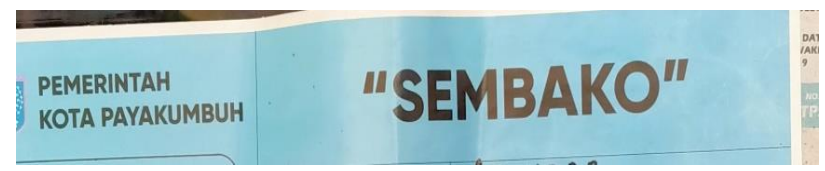

Source: primary data

Figure 8. Label or Sticker Groceries

In measuring the effectiveness of social assistance, the following variables are used, namely input variables, process variables, and output variables.

The following is a table of 6 overall variables used to calculate the effectiveness of social assistance in the city of Payakumbuh using Effectiveness according to Reference Ratio Research and Development Agency of Ministry of Internal Affairs as follows: 
Table 6. Calculation of the Effectiveness of Social Assistance in the city of Payakumbuh

\begin{tabular}{|c|c|c|c|c|c|}
\hline No & Variable & Target & Realization & Percent & $\begin{array}{l}\text { The effectiveness of } \\
\text { social assistance }\end{array}$ \\
\hline 1. & Goal Setting & 100 & 60 & 60.00 & Effective enough \\
\hline 2. & $\begin{array}{l}\text { Provisions on the Use of Social } \\
\text { Assistance Funds }\end{array}$ & 100 & 65 & 65.00 & Effective enough \\
\hline 3. & Socialization & 100 & 100 & 100.00 & Very effective \\
\hline 4. & Monitoring & 100 & 100 & 100.00 & Very effective \\
\hline 5. & $\begin{array}{l}\text { Level of Fulfillment of Basic } \\
\text { Needs }\end{array}$ & 100 & 74 & 74.00 & Effective enough \\
\hline & Total & 500 & 399 & 79.8 & Effective enough \\
\hline & Average & & & 79.8 & Effective enough \\
\hline
\end{tabular}

Source: Data processed by researchers 2020

Based on the results of the research described above, the effectiveness of mitigating the vulnerability of the community's economic welfare through the allocation of social assistance in the city of Payakumbuh can be seen from several indicators of effectiveness.

The input indicators are categorized as quite effective, namely $60 \%$. Because the KPM given has been right on target based on the criteria that have been determined by the Payakumbuh city government. The KPM referred to here are people who are included in the Social Welfare Integrated Data (DTKS) of the Indonesian Ministry of Social Affairs, and informal sector workers who are directly affected by the pandemic prevention policy such as mobile traders, small traders, public transport drivers, motorcycle taxis, workers who are laid off or laid off.

In the indicator for the use of social assistance funds, $65 \%$ was obtained based on the reference for the effectiveness of Research and Development for the Ministry of Home Affairs in 1991 which was stated to be quite effective because the distribution of social assistance that had been received was used for daily needs/ buying groceries, school needs during Covid-19 as a prevention of economic welfare vulnerability for the community affected by Covid-19.

The effectiveness of social assistance programs when viewed from the perspective of choice accuracy according to Makmur (2011), the accuracy of choice is the accuracy in choosing a need, job, etc. that will provide success. Based on the research results described above, it can be seen that so far the Payakumbuh Government's steps in distributing Covid-19 social assistance have been right on target. In determining the potential recipients of Covid-19 social assistance according to the criteria set by the government, even though in the field there are identified some people who are still not rightly receiving social assistance but based on the overall it can be said to be right on target, such as the work of KPM which has a MSME business. needing assistance funds for businesses affected by the pandemic can use alternative assistance from other governments, especially in the MSME section.

In terms of utilizing the choice of needs, KPM receives well whatever assistance is provided by the Government, the accuracy of the choice of needs here is stated to be quite effective because the beneficiary community uses the right social assistance funds for economic welfare, especially during the current pandemic such as meeting daily needs and so 
on. Although in the field there are identified as many as $27 \%$ of KPM assess and expect additional social assistance funds to want options not only for daily needs but also to be set aside for business capital. In this case, if for additional business capital, it can be transferred to the government's MSME program assistance. But based on the overall use of social assistance funds it can be said to be effective because the purpose of distributing social assistance allocations for the economic welfare of the people who are directly affected is due to the prevention of the COVID-19 pandemic.

Then the process indicators have been effective, where the percentage obtained is $100 \%$ for each indicator in the very effectiveness category according to the 1991 Ministry of Home Affairs Research and Development Effectiveness reference. The effectiveness of the process is determined by the ability of the organization to utilize its resources, management and use of technology so that can generate value. (Jones, 1993). One of the resources used in achieving the output of social assistance is the socialization process provided by the Social Service to environmental officials/ village heads and the monitoring of the distribution of social assistance after it is given to the community for BLT of the Ministry of Social Affairs, Provincial BLT and Municipal BLT, while for PKH and groceries there are assistants. who have the obligation to provide assistance in the social assistance mechanism or process.

The last indicator in the effectiveness of the distribution of social assistance during the pandemic in Payakumbuh city is output, where the output of social assistance that has been achieved is in the social welfare category with indicators of the level of fulfillment of needs where the percentage of $74 \%$ obtained is in the fairly effectiveness category according to the Ministry of Home
Affairs Research and Development Effectiveness reference. 1991. This can be seen from the responses or opinions of respondents about the effectiveness of social assistance received, with details that the assistance has been fully provided for economic welfare, especially in meeting daily needs.

Overall the allocation of social assistance distribution has a ratio of $79.8 \%$ which can be categorized as a fairly effective level of achievement according to the 1991 Ministry of Home Affairs Research and Development Effectiveness reference. It can be said that the social assistance provided by the Government can meet the daily needs of the people of Payakumbuh during the period. pandemic now.

According to Mursyidah (2017), a program or activity is considered effective if the output produced can meet the expected objectives. This statement is in line with Emalia's (2013) opinion where effectiveness is the suitability of output with set goals.

The main purpose of providing social assistance to people in the city of Payakumbuh is for the economic welfare of people affected by Covid-19, people whose work is dominant in the informal sector who directly feel the prevention of the Covid-19 pandemic through meeting their basic needs.

Several journals also state that the social assistance provided by the Government has been effectively implemented. According to Yuliantari \& Aswitari (2018), stating the effectiveness of social assistance for community welfare in Badung Regency is quite effective. According to Dinda Pramisita \& Made Suryana (2020) the effectiveness and influence of social assistance on the level of fulfillment of the basic needs of the elderly population in Mengwi subdistrict, Badung Regency based on the perception of the beneficiary community running very effectively, seen from the output variable, namely an increase in basic needs which reached $77.4 \%$ from 98 the elderly population in Mengwi District so that it can be 
said that this Elderly Social Assistance can increase the fulfillment of the basic needs of the elderly population there. Then with Jianguo's (2014) statement which said In 2006, China clearly stated that by 2020 , a comprehensive social security system covering both urban and rural residents would basically be established. Since then, the pace of improvement in social welfare for the elderly has increased.

\section{CONCLUSION}

The overall variable of the effectiveness of the allocation of social assistance distribution has a ratio of $79.8 \%$ which can be categorized as having a fairly effective level of achievement.

So that the implementation of the distribution of social assistance is more effective by the Government and the stackeholder, 1) Data transparency is needed. The central and local governments also need to have the same understanding of the criteria for beneficiaries. So that those who receive really need help. KPM data so far refers to Integrated Social Welfare Data (DTKS) compiled by the Ministry of Social Affairs. Seeing the fairly even distribution of underprivileged people, the central government needs to continue to improve synergy with local governments in terms of data collection. The participation of local governments, both at the district / city to provincial levels, is very crucial because it becomes the front mouthpiece to capture the situation in their respective regions. DTKS data collection is indeed carried out regularly. It's just that in the midst of a Corona pandemic situation like this, more and more people are affected and become vulnerable. So that data collection needs to be done to obtain accurate data which can then be processed at the central level as a reference for making policy based on facts in the field. In addition to re-data collection, a valid verification process of KPM data is also needed to ensure this assistance is right on target and has an impact on those entitled to receive it; 2) Socialization and monitoring by the Office of Social Affairs has been very effective. However, the intensity of socialization and monitoring is suggested to be more so that social assistance is really on target; 3) To support the realization of data on recipients of the PKH (Program Keluarga Harapan) program and sustainable basic foodstuffs to make it more accurate, the government can also conduct regular outreach. This is related to the lack of awareness of PKH Beneficiary Families (KPM) and groceries about the rights and obligations of KPM PKH and basic necessities according to applicable regulations as well as optimizing the functions and roles of $\mathrm{PKH}$ and groceries program facilitators who work in the field to be more concerned and responsive about conditions, situations and problems faced by KPM; 4) The level of fulfillment of basic needs is quite effective because some residents do not use it for its intended purpose. More outreach is needed for the purposes and benefits of providing social assistance; 5) The existence of uncertainty when the end of the pandemic requires the importance of anticipating the economic impact of a pandemic that lasts longer than expected. The World Health Organization (WHO) predicts that it will take 18 months to find a vaccine for Covid-19. As long as a vaccine has not been found, it is unclear how long Indonesia will implement a social distancing policy. Thus, as long as economic activity has not been running normally, the government needs to prepare a 
budget if the duration of the provision of social assistance must be extended.

As for the limitations in this study, namely in the form of flexibility in researching in the field related to the current pandemic situation and the prohibition of holding crowd activities in the midst of the community and not enough time in field observations because researchers have a job desk that must be done as well.

The suggestions that can be given to further researchers are 1) Can research more respondents who receive social assistance; 2) Can analyze the many types of social assistance issued by the government and which type of social assistance is most effective to be distributed to people who really need it; 3) The next researcher can add other variables related to the title that has been studied by the researcher; 4) And can analyze the impact before and after in the distribution of social assistance to the community when viewed from an economic point of view.

\section{REFERENCES}

Article 1, paragraph 6 of Government Regulation No. 21 of 2008 concerning disaster management. Definition of Disaster Mitigation

Aldino, P. A. (2018). The Effectiveness of the Implementation of Social Assistance Programs for Communities in Palu City (Study on Joint Business Groups). Catalogist, 6(8), 1-8. ISSN: 2302-2019.

Indonesian research and development agency Ministry of Internal Affairs., \& FISIPOL- UGM. (1991). Measurement of Level II Regional Financial Capability in the Context of Real and
Responsible Regional Autonomy. Jakarta: Gajah Mada University.

Bangun, H., Matias, S., \& Humaizi. (2019). The Effectiveness of The Ministry of Social Family's Hope Program in Increasing the Welfare of The District of Medan Johor, International Journal of Multireligious understanding, 125-134.

Budiani, N. W. (2007). The Effectiveness of Youth Youth Unemployment Program "Eka Taruna Bhakti, Sumerta Kelod Village, East Denpasar District, Denpasar City. Journal of Economics and Social Affairs, 2(1), 49-57.

Dinda, P., \& Utama, M. S. (2020). Effectiveness and Influence of Social Assistance to the Level of Fulfillment of Basic Needs of the Elderly in Mengwi District, Badung Regency. E-Journal of Development Economics, Udayana University, 9(4), 780-809.

Social Agency Affairs. (2020). Payakumbuh city

Emalia. (2013). Analysis of the Effectiveness of the Raskin Program in the City of Bandar Lampung. Journal of Applied Quantitative Economics, 6(1), 46-54.

Indrayani, F. K. (2014). The Effectiveness of the Family Hope Program in Sugihwaras Village, Saradan District, Madiun Regency. Public, 2(3), 1-11.

Infitah, N., et al. (2018). The Effectiveness of the Family Hope Program (Pkh) in Sumber Kejayan Village, Mayang District, Jember Regency. Journal of Economic Education: Scientific Journal of Educational Sciences, Economics, and Social Sciences, 12(1). doi: 10.19184/jpe.v13i2.11346.

Jianguo. (2014). Characteristics of China's Residual Welfare System For Elderly People. China Journal of Social Work, 7(3), 288-304. 
Jones, G. R. (1993). Organizational Theory: Text and Cases. New York: Wesley Publishing Company.

Law Number 21 of 2008 concerning Disaster Management.

Lydiana, et al. (2014). The Influence and Effectiveness of the Family Hope Program Assistance (PKH) on Education Participation in Muara Tiga District, Pidie Regency. Journal of Postgraduate Economics at Syiah Kuala University, 2(2).

Machfudz., et al. (2018). Analysis of the Implementation of Social Assistance for Persons with Social Welfare Problems (PMKS) in Sigi Regency. Catalogist, 6(5), 12-22.

Maftuchan, A., et al. (2020). Cash Program in the Era of COVID-19: Corona Cash Assistance or Universal Income Guarantee. Initiative Policy Brief. South Jakarta.

Makmur. (2015). Effectiveness of Institutional Supervision Policies. Bandung: PT. Refika Aditama.

Mardiasmo. (2010). Public sector accounting. Yogyakarta: Andi.

Mursyidah, L. (2017). The Effectiveness of the Conditional Cash Transfer Program in Overcoming Poverty and Hunger. JKMP (Journal of Public Policy and Management), 5(2), 245-260.

Rosaliana, A., \& Hardjati, S. (2019). The Effectiveness of the Implementation of the Non-Cash Food Assistance Program (Bpnt) in Wonocolo District, Surabaya City. Public Administration Journal, 2(2).

Sugiono. (2017). Quantitative Research Methods, Qualitative. Bandung: Alfabeta.
Timban, C. D., et al. (2015). The Effectiveness of the Work of the Manado City Government in the Flood Victim Assistance Program in Wanea District, Manado City. Journal of public administration, 2(30).

UUD 1945 Article 34 paragraphs 1 and 2 (2010).

Yuliantari, E. (2018). The Effectiveness and Impact of Social Assistance on the Welfare of KUBE Recipient Communities in Badung Regency. E Journal of Development Economics, Udayana University, 17(4), 773-805. 